\title{
Genesis of the Norm on Criminal Liability for Hostage Taking in Domestic Law
}

\author{
Anna V. Serebrennikova and Maksim V. Lebedev ${ }^{b *}$ \\ ${ }^{a}$ Lomonosov Moscow State University \\ Russian Federation, Moscow \\ ${ }^{b}$ Gubkin Russian State University of Oil and Gas \\ (National Research University) \\ Russian Federation, Moscow
}

Received 05.11.2019, received in revised form 31.08.2020, accepted 07.10.2020

\begin{abstract}
The widespread prevalence of terrorist crimes, as well as the problems of qualifying hostage taking and demarcation from related crimes, are currently relevant for scientific research. The theoretical and practical aspects contained in the norm on criminal liability for hostage taking have had a long and ambiguous history; they require studying the genesis of the norm on hostage taking and the practice of its application. The work contains only significant records of domestic jurisprudence, containing norms on criminal liability for hostage taking from origins up to the present. Methodology: deduction, induction, methods of synthesis, analysis, historical and formal logical research.

Conclusions: 1. The history of the application of the norm on criminal liability for hostage taking is fraught with qualification problems at all stages. These problems are ambiguous and are expressed by the fact that the legislator, under the influence of external and internal factors, makes mistakes in the systematization and codification of the criminal law, often losing the line between the norm and related crimes. As for external factors, in our understanding they are also the norms of international law on hostage taking, which, influencing the national law of the USSR, went through the stages of their development, creating norms by trial and error. For example, the rule did not apply if the taking occurred within the same state and the hostage and the perpetrators were its citizens.

2. The analysis of official statistics starting from the single crimes of the Soviet period, the post-perestroika mass crime boom of the 90 s of the last century caused by the political crisis, ending with the statistical recession and the relatively well-coordinated work of state structures of the 2000s allows us to conclude that there are calculus flaws.

3. The introduction of the category of public safety has led to a significant decrease in statistical indicators, due to qualifications through related crimes. In this regard, according to lawyers, the reduction in hostage taking has a technical or static character. This led to a proportional increase in qualifications in related crimes.

Scientific and practical significance: The study presented in the article gives an ontological
\end{abstract}

\footnotetext{
(C) Siberian Federal University. All rights reserved

* Corresponding author E-mail address: serebranna@hotmail.com,3g4g@mail.ru ORCID: 0000-0002-1064-4171 (Serebrennikova); 0000-0001-7199-5277 (Lebedev)
} 
idea of the development of the norm, reveals the technique of law making in the design of the norm on hostage taking. The conducted research is based on the materials of judicial practice in specific criminal cases, which may be of interest to researchers of this norm. These examples show the presence of law enforcement errors in the qualification of terroristic crimes, which can be perceived by practitioners as educational material.

The article can serve as a source of scientific information for students of law schools, graduate students and applicants, as well as for researchers involved in the study of the national criminal law of the Russian Federation.

Keywords: Criminal Code, qualification problems, criminal liability, genesis of the norm, public safety, terrorist act, hostage taking, hijacking of an aircraft.

Research area: law.

Citation: Serebrennikova, A.V., Lebedev, M.V. (2020). Genesis of the norm on criminal liability for hostage taking in domestic law. J. Sib. Fed. Univ. Humanit. Soc. Sci., 13(10), 1600-1609. DOI: $10.17516 / 1997-1370-0666$.

At the time of this writing, another message about the taking and killing of hostages appeared in the news agencies' feeds, this time it came from prosperous Switzerland. On 31 May 2019, in Zurich, an armed man took and held two women. Negotiations with the police failed, the criminal killed the hostages and then committed suicide ${ }^{1}$. In January of this year, another incident occurred at a branch of Suntrust Bank in Sebring, Florida ${ }^{2}$. Similar events often began to occur in other countries. At the same time, in the context of this study, we are interested in the connection between this crime and terrorism, which is carried out in legislation and can be traced in criminal law doctrinal studies, although it is not always observed in practice, as, for example, in the two recent cases mentioned above.

The criminal law literature usually uses the term "hostage" to mean an individual who is taken and further detained to compel the authorities, organizations or individuals to perform or not to perform a certain action under

\footnotetext{
1 Drei Tote in Zürcher Wohnung nach Schiesserei. SRF. (2019). Available at: https://www.srf.ch/news/schweiz/ geiselnahme-in-zuerich-drei-tote-in-zuercher-wohnung-nachschiesserei (accessed 30 September 2019)

2 Several people were injured while taking hostages and shooting at a bank in the USA (2019). In REN TV [REN TV]. Available at: https://ren.tv/novosti/2019-01-23/neskolkochelovek-raneny-pri-zahvate-zalozhnikov-i-strelbe-v-bankev-ssha (accessed 12 October 2019).
}

the threat of murder, harm, or further detention of the taken person ${ }^{3}$. From the standpoint of a civilizational approach, i.e. from a moral and ethical point of view, hostage taking is traditionally recognized as "one of the most unworthy crimes."

In accordance with the International Convention against the Taking of Hostages ${ }^{5}$ (hereinafter - the Convention), the taking of hostages is considered a manifestation of international terrorism. So it established that anyone who takes or holds a hostage, threatening with murder, bodily harm in order to force a third party (a state, an international organization, an individual or legal entity to perform or not to perform certain actions as a condition for the release of the hostage) commits the crime of taking a hostage.

\footnotetext{
3 International Convention against the Taking of Hostages. Adopted by UN General Assembly Resolution 34/146 of December 17, 1979. Available at: https://www.un.org/ru/documents/decl_conv/conventions/hostages.shtml (accessed 5 October 2019).

4 Hostage taking and tactics to counter these crimes (based on materials by Manfred Dikhanig, police adviser (2019). Mainz, Rhineland-Palatinate, Germany). Available at: flatik. ru/zahvat-zalojnikov-i-taktika-borebi-s-etimi-prestupleniyairii (accessed 05.21.2019).

5 Adopted by UN General Assembly Resolution 34/146 of December 17, (1979). Available at: https://www.un.org/ru/ documents/decl_conv/conventions/hostages.shtml (accessed 22 October 2019).
} 
The Russian legislator made a similar determination in the disposition of Part 1 of Art. 206 of the Criminal Code of the Russian Federation. These actions are punishable by 5-10-year imprisonment, and in the presence of qualifying signs of the crime - by 6 -year imprisonment up to life sentence. In accordance with the Note to this article, a person who voluntarily or at the request of the authorities released a hostage is exempted from criminal liability, provided that there is no other corpus delicti in his actions.

The criminalization of these acts and the sanctions stipulated in Russian criminal legislation are in accordance with international law on the basis that the UN classifies hostage taking as crimes "of serious concern to the international community." In this regard, and also on the basis of the Convention in question, the person who took the hostage is liable to criminal prosecution or extradition.

This is primarily due to the fact that the right to life, health and freedom of expression are universally recognized fundamental human rights. The 1950 European Convention for the Protection of Human Rights and Fundamental Freedoms proclaims the right of everyone to life, which no one can be deliberately deprived of (Part 1 of Art. 2). No one should be subjected to torture, inhuman or degrading treatment, or punishment (Art. 2). In accordance with the Convention, no one should be held in slavery or other servitude (Part 1 of Art. 3). Thus, a person has the right to freedom, which can be limited only in accordance with criminal and criminal procedure law (Part 1 of Art. 4) ${ }^{7}$. Part 1 of Art. 20, Part 1 of Art. 22, Part 1 of Art. 23 of the Constitution of the Russian Federation of 1993 guarantee these rights. The state undertook obligations to ensure and protect them. Taking hostages grossly violates these rights in unlawful interests. In this regard, Russian researchers are generally unanimous that "the norm on liability and punishment for hostage

\footnotetext{
6 Ibid.

7 The official text on the official website of the European Convention for the Protection of Human Rights. Available at: www.echr.ru/documents/doc/2440800/ 2440800-001.htm (accessed 5 October 2019).
}

taking is borrowed by domestic criminal law mainly from public international law."

The implementation of the analyzed norm in the domestic legislation of our country has taken place relatively recently. Note that the norms establishing criminal liability for hostage taking appeared already in the early acts of the feudal period, such as the Pskov Judgment Book, the Code of Laws of 1497, the Code of Laws of 1550, the Cathedral Code of 1649, the Military Code of Peter I of 1715 , which provided for punishment for similar crimes.

In the days of the Russian Empire, criminal law doctrine first mentioned such a crime as kidnapping. In particular, the works of P.I. von Feuerbach, published in St. Petersburg in 1810 considered these crimes among others. They included the modern understanding of hostage taking'.

The Code of Laws of the Russian Empire in 1832, as well as the Code of Criminal and Correctional Punishments of 1845 in Articles 1540-1544 provided penalties for detention, abduction and unlawful confinement, which were defined as "willful deprivation of freedom of movement through unlawful taking of the person." Abduction was understood as "physical capture ... with various purposes", which the law differentiated "by property" "into the slave trade, the concealment or change of the origin of the infant and the abduction of women." 10 The last Russian Criminal Code of 1903 in Ch. 26 "On Criminal Acts Against Personal Freedom" also provided for articles (Articles 498-512), providing for

\footnotetext{
8 Samovich, Yu.V. (2012). O poniatii «mezhdunarodnyi terrorizm» [On the concept of "international terrorism"]. In Vestnik Tomskogo gosudarstvennogo universiteta [Bulletin of Tomsk State University], 361, 120-123; Chernykh, S.A. (2009). Zakhvat zalozhnika: ot obyknoveniia k prestupleniiu terroristicheskogo kharaktera [Hostage taking: from practice to a crime of a terrorist nature]. In "Chernye dyry» $v$ rossiiskom zakonodatel'stv.e Iuridicheskii zhurnal [Black Holes in Russian law. Law Journal], 1, 121-123.

9 Foynitsky, I.Ya. (1900). Kurs ugolovnogo prava [Criminal law course]. St. Petersburg, 86-88 p.

${ }^{10}$ Tagantsev, N.S. (1909). Ulozhenie o nakazaniiakh ugolovnykh i ispravitel'nykh 1885 goda [The Legal Code of Criminal and Correctional Sentences (1885)]. St. Petersburg, $881 \mathrm{p}$
} 
criminal liability for crimes against personal freedom called kidnapping ${ }^{11}$.

The Soviet criminal law did not contain special provisions on the taking of hostages. The Criminal Code of the RSFSR of $1922^{12}$ (Art. 159) contained a norm on criminal liability for violent unlawful deprivation of liberty in the form of detention or retention. It also provided for punishment for imprisonment in a manner dangerous to life or health, or accompanied by torment (Art. 160 of the Criminal Code of the RSFSR). Criminal liability for kidnapping with a mercenary or other illegal purpose, concealment or substitution of a child was introduced (Art. 162).

The Criminal Code of the RSFSR of 1926 provided for punishment for violent unlawful imprisonment (Art. 147), including in a manner dangerous to life or health, or accompanied by the infliction of physical suffering. Also, the norm on the abduction, concealment or substitution of a child (Art. 149) ${ }^{13}$ was maintained. At the same time, these norms did not contain any signs of a modern understanding of hostage taking crime. Perhaps, this is due to the fact that such crimes were not typical for the USSR and the norms on abduction were sufficient for the Soviet law enforcement officer at that period.

In addition, one cannot fail to take into account that the NKVD-GPU-NKGB bodies actually used the practice of taking hostages, arresting family members of persons accused or suspected of committing state (political) crimes, or persons who held positions of responsibility and thus seeking to prove their loyalty ... For the example, the arrest and exile (1949-1953) of P.S. Zhemchuzhina, the wife of the Deputy Chairman of the Council of People's Commissars and Minister of Foreign Affairs of the USSR V.M. Molotov, was notoriously ab$\operatorname{surd}^{14}$. In fact, she was taken hostage, and Mo-

\footnotetext{
${ }^{11}$ Pertli, L.F. (2011). Pravovoe regulirovanie uslovii soderzhaniia zakliuchennykh v Rossiiskoi imperii [Legal regulation of prisoners' conditions in the Russian Empire]. In dissertatsiia kandidata iuridicheskikh nauk [Thesis for a PhD Degree in Law Sciences]. Vladimir, $11 \mathrm{p}$.

${ }_{12}$ Criminal Code of the RSFSR. (1922). 15, Art. 153.

${ }^{13}$ Collection of legalizations of the RSFSR. (1926), 80. Article. 600 .

${ }^{14}$ She was accused of "being in a criminal relationship with Jewish nationalists, she conducted enemy work against the
}

lotov, while continuing to remain the second person in the state, had to prove his loyalty.

The 1960 Criminal Code of the RSFSR ${ }^{15}$ retained criminal liability for the abduction (substitution) of a child for any purpose (Art. 125 of the RSFSR Criminal Code), as well as illegal imprisonment, including with danger to life or health, accompanied by the infliction of physical suffering (Art. 126 of the Criminal Code of the RSFSR).

Russian researchers explain the absence of special criminalization of hostage taking in Soviet criminal law by the fact that this crime was then (until the mid-1980s) "quite rare"16. It is difficult to agree with this position. The taking of hostages, as a percentage of other common crimes, was really negligible, but the cases that took place were repeated annually, tended to grow and were the most dangerous to the public. According to our calculations, in the 1970s, the USSR annually recorded an average of 5-6 cases of hijacking, accompanied by hostage taking ${ }^{17}$. The already mentioned taking and hijacking of An-24B (Batumi-Sukhumi flight) to Turkey on October 15,1970 by the father and son Brazinskas is best known ${ }^{18}$. This forced the Soviet legislator on January 3, 1973 to introduce criminal liability for the hijacking of an aircraft (Art. 213.2 of the RSFSR Criminal Code), which from that moment was qualified independently. Additionally, all flights were accompanied by armed police officers.

party and the Soviet government." All her relatives were also arrested, some of whom died as a result of torture. Kostyrchenko, G.S. (2009). Stalin protiv «kosmopolitov». Vlast' i evreiskaia intelligentsiia $\mathrm{v}$ SSSR [Stalin against the "cosmopolitans". Power and Jewish intelligentsia in the USSR]. In ROSSPEN [ROSSPEN]. Moscow, $415 \mathrm{p}$.

15 The Criminal Code of the RSFSR. In Vedomosti VS RSFSR. (1960). 40. Art. 591

${ }^{16}$ Kiselev, E. P., The emergence and development of the criminal law norm "hostage taking" in domestic law. In Institute Herald: crime, punishment, correction, 4 (36). 19-23p.

171970 - 5 hijackings (including attempts), $1971-5$; 1976 $3 ; 1977-5 ; 1978-7 ; 1979-4 ; 1980-5 ; 1982-3 ; 1983-5$; $1984-4$ etc. The record was set in 1990-31 incidents / Komissarov, V.S. (2009). Vozdushnye piraty Strany Sovetov [Air pirates of the Country of Soviets]. In Aviatsiia i vremia [Aviation and time $], 5$.

${ }^{18}$ Gubarev, O.I. (2006). Vozdushnyi terror: khronika prestuplenii [Air terror: a chronicle of crimes]. In Veche [Veche]. Moscow, $320 \mathrm{p}$. 
Criminalization and additional measures did not change the situation. Already on May 18 of the same year, the Tu-104A (Irkutsk-Chita) was hijacked. An escorting policeman shot the terrorist, but a powerful improvised explosive device destroyed the plane, killing 72 passengers and 9 crew members ${ }^{19}$.

In this regard, it is difficult to agree with the position that the taking of civilian planes and passengers as hostages "were isolated" and, due to their rarity, "did not pose a public danger on a national scale." ${ }^{20}$ At the same time, the increase in riots in Soviet correctional institutions was almost always accompanied by the taking of hostages, after which the latter began to be recognized as dangerous ${ }^{21}$.

Around the same time, in the late 1970s, the international community recognized hostage taking as a serious crime ${ }^{22}$. The UN General Assembly in 1979 adopted the International Convention on the Taking of Hostages ${ }^{23}$, which, however (Art. 13), was not applied when the taking was committed within one state and the hostage and the perpetrators were its citizens. Thus, international law considered hostage taking as crimes provided for by both international and national criminal law.

The USSR ratified this Convention in 1987 and introduced the corresponding norm into the Criminal Code of the RSFSR - Art. 126.1. ${ }^{24}$ The disposition of the then adopted version of the original contained an indication of the taking or retention of a person as a hostage, in

\footnotetext{
19 Drozdov, S.I. (2009). Vozdushnye piraty Strany Sovetov [Air pirates of the Country of Soviets]. In Aviatsiia i vremia [Aviation and time], 3.

20 Severin, Yu.D. (1980). Kommentarii k Ugolovnomu kodeksu RSFSR [Commentary on the Criminal Code of the RSFSR]. Moscow, 258 p.

${ }^{21}$ Kozlova, N.N. (1992). Ugolovnaia otvetstvennost' za zakhvat zalozhnikov [Criminal liability for hostage taking]. In dissertatsiia kandidata iuridicheskikh nauk [Thesis for a PhD Degree in Law Sciences]. Moscow, 67 p.

22 Ovchinnikov, S.N. (2015). Pozhiznennoe lishenie svobody v pravovykh sistemakh FRG i Rossii: sravnitel'no-pravovoi analiz [Life imprisonment in the legal systems of Germany and Russia: comparative legal analysis]. In Bulletin of the Volgograd Academy of the Ministry of Internal Affairs of Russia, 3 (34). 206 p.

23 Resolutions and decisions adopted by the General Assembly at the 34th session. New York, (1980).

${ }^{24}$ Vedomosti of the Supreme Council of the RSFSR. (1987), 30. Article 1087 .
}

the presence of a threat of murder, infliction of injury or continued detention in order to force a state, an international organization, an individual or legal entity, or a group of persons, as a condition for the release of the hostage, to perform (not perform) the action specified by the invader.

It is important that the note introduced in accordance with Art. 13 of the Convention of 1979 hindered the effective implementation of the original version. This restriction extended to cases of taking a hostage - a citizen of a foreign state, while the taking of a citizen of the USSR was not qualified as a hostage taking, but as an illegal imprisonment (Art. 126 of the RSFSR Criminal Code, 1960). In the first case, the sanction could reach 15 years in prison, while in the second - only three years. In addition, this norm could not be applied when taking hostages on the territory of the USSR, if citizens of the USSR became such, and the invaders were also Soviet citizens. In this sense, essentially identical acts had significantly different legal assessments ${ }^{25}$, far from fully fulfilling the function of criminal law protection of the relevant relations.

At the turn of 1980-1990 the growth of phenomena that were characteristic of the socio-economic and political crisis, the prevalence of hostage taking in detention facilities, as well as the taking of hostages from among the first entrepreneurs and members of their families, with the aim of extorting ransom, forced the Russian legislator to amend the Criminal Code of the RSFSR ${ }^{26}$. The note was removed from Art. 126.1, which extended the effect of the corpus delicti to all types of its commission, which now did not depend on the citizenship of the hostage and the hijacker. The innovation dramatically changed the statistics. The number of registered hostage taking cases increased by 17 times. If in 1991 there were no cases at all, in 1992 there were

\footnotetext{
${ }^{25}$ Belous V.G., Golodov P.V., Pertley L.F. (2015). Pravoprimenitel'naia sistema Rossii v sovremennoi istoriografii [The law enforcement system of Russia in modern historiography]. In Aktual'nye voprosy obrazovaniia i nauki [Topical Issues of education and science], 3-4. 42-51.

${ }^{26}$ The Law of the Russian Federation of February 18, (1993) 4512-1 "On Amendments and Additions to the Criminal Code of the RSFSR".
} 
only 3 cases, in 1993 - 51 cases, in $1994-118$ cases, then in 1995 there were already 11316 cases $^{27}$.

The article used in this case was included in Ch. 3 of the Criminal Code of the RSFSR "Crimes against life, health, freedom and dignity of the individual", respectively, the generic object was defined as relations that ensure life, health and dignity of the individual. The immediate object was personal freedom. This position was doctrinally confirmed ${ }^{28}$. At the same time, the totality of objective and subjective signs of hostage taking testified that this socially dangerous act gravitates towards the sphere of crimes against public safety, which was taken into account in the new Criminal Code of the Russian Federation in 1996. The norm on hostage taking (Art. 206) here was placed in Ch. 24 "Crimes Against Public Safety." Thus, the species object was defined as a public safety relationship.

According to E.P. Kiselev, this was the reason for the decrease in the number of acts classified as "hostage taking." The author refers to criminological research. So, in 1997 there were 114 registered cases, in $1998-69$ cases, in 1999 - 64 cases, in 2000 - 49 cases, in $2001-32$ cases. According to E.P. Kiselev, the decline was purely statistical, since the total set of similar crimes was redistributed according to similar crimes:

- kidnapping (Art. 126 of the Criminal Code of the Russian Federation) (in 1997 1140 , in $1998-1415$, in $1999-1554$, in $2000-$ 1291, in 2001 - 1417);

- illegal imprisonment (Art. 127 of the Criminal Code of the Russian Federation) (in 1997 - 101, in $1998-1278$, in $1999-1417$, in $2000-1365$, in $2001-1314)^{29}$.

\footnotetext{
27 Kiselev, E.P. Op. cit.

${ }^{28}$ Kozlova, N.N. (1992). Nekotorye voprosy sovershenstvovaniia ugolovno-pravovoi normy o zakhvate zalozhnikov [Some issues of improving the criminal law on hostage taking]. In Pravovye problemy deiatel'nosti organov vnutrennikh del v sovremennykh usloviiakh [Legal problems of the activities of internal affairs bodies in modern conditions]. Moscow, 78 p; Loskutov, A.G. (1992). On the issue of criminal liability for hostage taking. In Improving the activities of internal affairs bodies in the context of legal reform, Moscow. 2, 45 p; Lysov, M. (1994). Responsibility for illegal imprisonment, kidnapping and hostage taking. In Russian Justice, 5. 40-41 p. ${ }^{29}$ Kiselev, E.P., Op. cit.
}

According to statistics from the Judicial Department under the Supreme Court of the Russian Federation, 5-6 hostage taking cases, about 340 kidnappings and about 200 illegal imprisonment were committed annually in Russia in $2015-2018^{30}$. At the same time, based on the fact that according to statistics, in more than $80 \%$ of cases, hostages in Russia are taken with the use of weapons or other items ${ }^{31}$.

In connection with the international recognition of terrorism as one of the global challenges, in the Russian literature, when discussing the issues of minimizing security threats in the form of terrorism, extremism, religious radicalism, there were proposals to adjust the structure of Section 9 of the Criminal Code of the Russian Federation, singling out "Terrorist crimes", which mean terrorist acts, hostage taking, as well as for some reason banditry, the organization of an illegal armed group ${ }^{32}$, which may not be related to terrorism, in a separate chapter.

At the same time, taking into account the lack of a legal definition of a "crime of a terrorist nature", these proposals are criticized from the position that the hostage taking is fully covered by the components of a terrorist act. Yu.S. Gorbunov proposed here to proceed from the differentiation of crimes related to terrorism:

1) the acts themselves - Art. 205 of the Criminal Code of the Russian Federation ("Terrorist act"), Art. 206 of the Criminal Code of the Russian Federation ("Hostage taking"), Art. 211 of the Criminal Code of the Russian Federation ("Hijacking of an aircraft or water transport or railway rolling stock");

2) assistance to such acts - Art. 205.1 of the Criminal Code of the Russian Federation ("Assistance in terrorist activities"), Art. 205.2 of the Criminal Code of the Russian Federation

\footnotetext{
30 Bulletin of the Congress of People's Deputies of the Russian Federation and the Supreme Council of the Russian Federation (1993), 10. Art. 362.

31 Antsiferov, K.P. (2003). Otvetstvennost' za zakhvat zalozhnika (ugolovno-pravovoi i kriminologicheskie aspekty) [Responsibility for hostage taking (criminal law and criminological aspects)]: thesis for a PhD Degree in Law Sciences. Moscow, $18 \mathrm{p}$.

32 Kashepov, V.P. (2005). Ob osobennostiakh sovremennogo ugolovno-pravovogo zakonotvorchestva [On the features of modern criminal law-making]. In Zhurnal rossiiskogo prava [Journal of Russian Law], 4. 19 p.
} 
("Public calls for terrorist activity or public justification of terrorism" $)^{33}$.

In any case, in spite of the absence of a legally fixed definition of a "crime of a terrorist nature," the doctrine suggests that hostage taking should be considered a terrorist crime $^{34}$. S.A. Chernykh recognizes this act as "directly and indirectly related to terrorism and terrorist activities", referring to Art. 3 of the Federal Law of March 6, 2006 No. 35-FZ "On Countering Terrorism".

Russian jurisprudence contradicts these provisions. Let us give a typical example ${ }^{35}$. The court established that on February 8, 2015 a certain Mr. P, having previously committed several thefts and being in a state of alcoholic intoxication, came to his wife's mother Ms. B. to find out the location of her daughter Mss. I. in an aggressive manner. Fearing violence, Ms. B. tried to escape. At that moment, Mr. P. "had a direct criminal intent aimed at taking and then holding Ms. B. as a hostage" in order to compel her daughter Mss. I. to bring their common little daughter to him. The court found that Mr. P., "realizing his direct criminal intent aimed at taking and then holding the hostage," armed with a knife, "with the aim of taking and holding Ms. B. as a hostage," attacked Ms. B. and forcibly held her, compelling his wife Mss. I. to bring their common little daughter. Upon the arrival of the police officers, Mr. P. began to demand this (as well as a bottle of vodka and a machine gun) from them, making the fulfillment of the requirements a condition for the

\footnotetext{
${ }^{33}$ Gorbunov, Yu. S. (2008). O nekotoryh problemah sovershenstvovaniya pravovogo regulirovaniya protivodejstviya terrorizmu [The some problems of improving the legal regulation of counteraction to terrorism]. In Zhurnal rossiiskogo prava [Journal of Russian Law], 7.21 p.

${ }^{34}$ Chernykh, S.A. (2009). Bor'ba s zakhvatom zalozhnika: otechestvennyi i zarubezhnyi opyt [Countering the taking of hostages: domestic and foreign experience]. In Probely $v$ rossiiskom zakonodatel'stve. Iuridicheskii zhurnal [Gaps in Russian law. Law Journal], 1. 212 p.

35 Sentence of the Kasimovsky District Court of the Ryazan Region of November 10, 2015. Available at: https://advokat15ak.ru/приговор-по-статье-206-ук-рф-захват-залож.
}

release of his wife's mother, held as a hostage, whom he threatened to kill. As a result, Ms. B. was released by the police officers, who used firearms. It is obvious that in this case, the actions of Mr. P, who was threatening his family in a state of intoxication, are far from terrorism in its international legal and simply rational understanding, which, however, did not prevent the court from proceeding precisely from this qualification, according to which Mr. P. was sentenced to 7 years of imprisonment.

Thus, the legislation of the Russian Federation against the taking of hostages has had a long history of evolution and coexistence with related (similar) offenses. At the same time, the idea of this act as a kidnapping, for which it has always been classified as a serious crime with a severe punishment for it, dominated in Russian criminal law and criminal law doctrine.

The actual hostage taking, considered as a crime until 1987, was absent in the domestic criminal legislation, which applied the norms of encroachment on freedom in the form of illegal detention, imprisonment, abduction and deprivation of liberty.

The singling out of hostage taking was the result both of a significant increase in the number of such cases and the development of international law in the field of countering international terrorism.

Today, hostage taking, along with other terrorist crimes, poses a threat both to the entire world community as a whole and to an individual state in particular. Without diminishing the importance of the individual personality of the hostage, characterized by such benefits as life and health, we emphasize that the distinguishing feature of this crime is the object-public safety. Problems of qualification of crimes encountered in practice call for an analysis of the genesis of the hostage taking norm, examining the origins of domestic legislation. This article is devoted to the study of the search for legal approaches of the Russian state on the criminalization of hostage taking. 


\section{References}

Antsiferov, K.P. (2003). Otvetstvennost' za zakhvat zalozhnika (ugolovno-pravovoi i kriminologicheskie aspekty) [Responsibility for hostage taking (criminal law and criminological aspects)]: thesis for a PhD Degree in Law Sciences. Moscow, 18 p.

Belous, V.G., Golodov, P.V., Pertley, L.F. (2015). Pravoprimenitel'naia sistema Rossii v sovremennoi istoriografii [The law enforcement system of Russia in modern historiography]. In Aktual'nye voprosy obrazovaniia $i$ nauki [Topical Issues of Education and Science], 3-4. 42-51.

Chernykh, S.A. (2009). Bor'ba s zakhvatom zalozhnika: otechestvennyi i zarubezhnyi opyt [Countering the taking of hostages: domestic and foreign experience]. In Probely v rossiiskom zakonodatel'stve. Iuridicheskii zhurnal [Gaps in Russian law. Law Journal], 1. 212 p.

Gorbunov, Yu.S. (2008). O nekotorykh problemakh sovershenstvovaniia pravovogo regulirovaniia protivodeistviia terrorizmu [On some problems of improving the legal regulation of countering terrorism]. In Zhurnal rossiiskogo prava [Journal of Russian Law], 7.

Gubarev, O.I. (2006). Vozdushnyi terror: khronika prestuplenii [Air terror: a chronicle of crimes]. In Veche [Veche]. Moscow, $320 \mathrm{p}$.

Drei Tote in Zürcher Wohnung nach Schiesserei. SRF. (2019). Available at: https:/www.srf.ch/news/schweiz/geiselnahme-in-zuerich-drei-tote-in-zuercher-wohnung-nach-schiesserei_(accessed 30 September 2019)

Drozdov, S.I. (2009). Vozdushnye piraty Strany Sovetov [Air pirates of the Country of Soviets]. In Aviatsiia i vremia [Aviation and time], 3.

Foynitsky, I.Ya. (1900). Kurs ugolovnogo prava [Criminal law course]. St. Petersburg, 86-88 p.

Hostage taking and tactics to counter these crimes (based on materials by Manfred Dikhanig, police adviser (2019). Mainz, Rhineland-Palatinate, Germany). Available at: flatik.ru/zahvat-zalojnikov-i-taktika-borebi- s-etimi-prestupleniyairii (accessed 05.21.2019).

International Convention against the Taking of Hostages. Adopted by UN General Assembly Resolution 34/146 of December 17, 1979. Available at: https:/www.un.org/ru/documents/decl_conv/conventions/ hostages.shtml (accessed 5 October 2019).

Kashepov, V.P. (2005). Ob osobennostiakh sovremennogo ugolovno-pravovogo zakonotvorchestva [On the features of modern criminal law-making]. In Zhurnal rossiiskogo prava [Journal of Russian Law], 4. 19 p.

Kiselev, E.P. (2016). Vozniknovenie i razvitie ugolovno-pravovoi normy «zakhvat zalozhnika» v otechestvennom zakonodatel'stve [The emergence and development of the criminal law norm "hostage taking" in domestic law]. In Vestnik instituta: prestuplenie, nakazanie, ispravlenie [Institute Herald: crime, punishment, correction], 4 (36). 19-23.

Komissarov, V.S. (2009). Vozdushnye piraty Strany Sovetov [Air pirates of the Country of Soviets]. In Aviatsiia $i$ vremia [Aviation and time], 5.

Kostyrchenko, G.S. (2009). Stalin protiv «kosmopolitov». Vlast' i evreiskaia intelligentsiia v SSSR [Stalin against the "cosmopolitans". Power and Jewish intelligentsia in the USSR]. In ROSSPEN [ROSSPEN]. Moscow, $415 \mathrm{p}$.

Kozlova, N.N. (1992). Nekotorye voprosy sovershenstvovaniia ugolovno-pravovoi normy o zakhvate zalozhnikov [Some issues of improving the criminal law on hostage taking]. In Pravovye problemy deiatel'nosti organov vnutrennikh del $v$ sovremennykh usloviiakh [Legal problems of the activities of internal affairs bodies in modern conditions]. Moscow, $78 \mathrm{p}$.

Kozlova, N.N. (1992) Ugolovnaia otvetstvennost' za zakhvat zalozhnikov [Criminal liability for hostage taking]. In dissertatsiia kandidata iuridicheskikh nauk [Thesis for a PhD Degree in Law Sciences]. Moscow, 67 p.

Severin, Yu.D. (1980). Kommentarii k Ugolovnomu kodeksu RSFSR [Commentary on the Criminal Code of the RSFSR]. Moscow, $258 \mathrm{p}$.

Several people were injured while taking hostages and shooting at a bank in the USA (2019). In REN TV [REN TV]. Available at: https://ren.tv/novosti/2019-01-23/neskolko-chelovek-raneny-pri-zahvatezalozhnikov-i-strelbe-v-banke-v-ssha (accessed 12 October 2019). 
Ovchinnikov, S.N. (2015). Pozhiznennoe lishenie svobody v pravovykh sistemakh FRG i Rossii: sravnitel'no-pravovoi analiz [Life imprisonment in the legal systems of Germany and Russia: comparative legal analysis]. In Bulletin of the Volgograd Academy of the Ministry of Internal Affairs of Russia, 3 (34). 206 p.

Pertli, L.F. (2011). Pravovoe regulirovanie uslovii soderzhaniia zakliuchennykh v Rossiiskoi imperii [Legal regulation of prisoners' conditions in the Russian Empire]. In dissertatsiia kandidata iuridicheskikh nauk [Thesis for a PhD Degree in Law Sciences]. Vladimir, $11 \mathrm{p}$.

Prigovor Kasimovskogo raionnogo suda Riazanskoi oblasti [The verdict of the Kasimovsky District Court of the Ryazan Region] (2015). In MGKA [Moscow City Bar Council]. Available at: https://advokat15ak.ru/ sentence-post-206-uk-rf- capture- mortgage/ (accessed 19 September 2019).

Samovich, Yu.V. (2012). O poniatii «mezhdunarodnyi terrorizm» [On the concept of "international terrorism"]. In Vestnik Tomskogo gosudarstvennogo universiteta [Bulletin of Tomsk State University], 361, $120-123$.

Tagantsev, N.S. (1909). Ulozhenie o nakazaniiakh ugolovnykh i ispravitel'nykh 1885 goda [The Legal Code of Criminal and Correctional Sentences (1885)]. St. Petersburg, 881p.

Ugolovnyi kodeks RSFSR (1960) [The Criminal Code of the RSFSR (1960)]. In Vedomosti VS RSFSR [Bulletin of Armed Forces of the RSFSR], 40, Article 591.

Ugolovnyi Kodeks RSFSR 1922 goda [Criminal Code of the RSFSR 1922]. Available at: law.edu.ru/ norm/norm.asp?normID=1241523\&subI (accessed 19 September 2019).

Ugolovnyi Kodeks RSFSR 1926 goda [The Criminal Code of the RSFSR 1926]. Available at: ru.wikisource.org/wiki/\%D0\%A3\%D0\%. (accessed 19 September 2019).

\title{
Генезис нормы об уголовной ответственности за захват заложника в отечественном законодательстве
}

\author{
А.В. Серебренникова ${ }^{a}$ М.В. Лебедевб \\ ${ }^{a}$ Московский государственный университет им. М. В. Ломоносова \\ Российская Федераџия, Москва \\ ${ }^{6}$ Российский государственный университет нефти и газа \\ (Национальный исследовательский университет имени И. М. Губкина) \\ Российская Федерация, Москва
}

\begin{abstract}
Аннотация. Широкая распространенность преступлений террористической направленности, а также проблемы квалификации захвата заложников и отграничения от смежных составов являются на сегодняшний день актуальными для научного исследования. Теоретические и практические аспекты, содержащиеся в норме об уголовной ответственности за захват заложника, имеют долгую и неоднозначную историю, требуют исследования генезиса нормы о захвате заложника и практике ее применения. В работе приведены только значимые памятники отечественной юриспруденции, содержащие нормы об уголовной ответственности за захват заложников, от истоков до настоящего времени. Методология: дедукция, индукция, методы синтеза, анализа, исторического и формально-логического исследования.

Выводы: 1. История применения нормы об уголовной ответственности за захват заложников сопряжена на всех этапах с проблемами квалификации. Эти проблемы неоднозначны и выражены тем, что законодатель под воздействием внешних и внутренних факторов допускает ошибки в систематизации и кодификации уголовного закона, часто утрачивая грани между нормой и смежными составами. Под
\end{abstract}


внешними факторами можно понимать и нормы международного права о захвате заложников, которые, оказывая воздействие на национальное право СССР, также переживали этапы своего развития, создавая нормы методами «проб и ошибок». Например, норма не распространялась, если захват совершался в пределах одного государства и заложник и виновные лица были его гражданами. 2. Анализ официальной статистики: от единичных преступлений советского периода, постперестроечного бума массовой преступности 90-х годов прошлого столетия, вызванных политическим кризисом, до статистического спада и сравнительно слаженной работы государственных структур периода 2000-х годов, позволяет сделать вывод о имеющихся пороках исчисления. 3. Введения категории «общественная безопасность» привела к значительному снижению статистических показателей ввиду квалификации через смежные составы. В связи с этим, по мнению правоведов, снижение захватов заложников имеет технический или статический характер. Это способствовало пропорциональному увеличению квалификаций по смежным составам. Проведенное исследование дает онтологическое представление о развитии нормы, раскрывает технику законоискусства при конструировании нормы о захвате заложников. Оно базируется на материалах судебной практики по конкретным уголовным делам, что может представлять интерес для исследователей данной нормы. Указанные примеры демонстрируют наличие ошибок правоприменителя при квалификации преступлений террористической направленности, что может быть воспринято практическими работниками в качестве учебно-методического материала. Статья может послужить источником научной информации для студентов юридических вузов, аспирантов и соискателей, а также для научных сотрудников, занимающихся исследованием национального уголовного законодательства Российской Федерации.

Ключевые слова: Уголовный кодекс, проблемы квалификации, уголовная ответственность, генезис нормы, общественная безопасность, террористический акт, захват заложников, угон воздушного судна.

Научная специальность: 12.00 .00 - юридические науки. 